Journal of Money and Economy

Vol. 15, No. 4, Fall 2020

pp. $463-487$

DOI: $10.29252 /$ jme.15.4.463

Original Research Article

\title{
Modeling of Real Estate Income Tax: System Dynamics Approach
}

\begin{tabular}{ll}
\hline $\begin{array}{l}\text { Manouchehr Hazarati* } \\
\text { Samad Aali }\end{array}$ & Alireza Bafandeh Zendeh \\
\hline Received: 26 Sep 2020 & Approved: 20 Feb 2021 \\
\hline
\end{tabular}

This study aims to design a model to realize real estate income tax in Tabriz city with due attention to the tax collection process. According to the related literature, the variables of "tax payment," "real estate," "tax evasion," "investment incentive," "rent and real estate speculation," and "advertisement in tax collection" are considered as key variables, affecting the conceptual model of real estate tax system. According to the dynamic systems method, the interaction and relationships between variables are shown by state-flow diagrams based on the literature and experts' opinions. These relationships are finally simulated by Vensim software. The results show that advertisement has a significant effect on the amount of taxes paid by taxpayers. Tax transparency has also reduced rents for taxpayers and ultimately reduced tax evasion and timely tax collection in the estimated budget of real estate resources and single-occupancy jobs. Scenarios show that lowering the tax rate in the trading and business market and large corporations and businesses' rental income are strongly influenced by tax revenues.

Keywords: Real Estate Income Tax, Income Tax Jobs, System Dynamics, Economic Rent, Speculation

JEL Classification: N12, N25, P43, P44, O42

\section{Introduction}

In most countries, especially developed ones, tax as a major public financial recourse in the budget income sector, covers significant public expenses. Tax laws are effective tools influencing economic development, paving the way for dynamic and productive directions at the face of any given country's economy (Diamond \& Saez, 2011).

\footnotetext{
* Department of Management, Tabriz Branch, Islamic Azad University, Tabriz, Iran, hazrati_1922@yahoo.com

$\dagger$ Department of Management, Tabriz Branch, Islamic Azad University, Tabriz, Iran, a.b.zendeh@gmail.com (Corresponding Author)

$¥$ Department of Management, Tabriz Branch, Islamic Azad University, Tabriz, Iran, samad.aly@gmail.com
} 
Financial information practices are increasingly developed to meet the needs of capital markets. On the contrary, tax practices are always a matter of law and formed to manage the objectives of social policy. States may lose revenue due to tax misconducts, wrong transfer invoices, risk counterbalance, overuse of tax motives, and other tax planning systems (Sikka, 2017). It is of significant matter to correctly plan taxation in a state.

Real estate income tax includes a tax on empty properties and properties' transfer and business rights. Real estate income tax, notwithstanding the degree of development in any given country, is a strong tool for all countries and contributes to investment creation by landlords and by establishing jobs via the side of related leased properties (McCluskey, et al., 2007).

Models in optimal tax theory typically posit that the tax system should maximize a social welfare function subject beyond a government budget constraint. It creates the classical trade-off between equity and efficiency, which is at the core of the optimal income social trade-off between equity and efficiency. In general, optimal tax analyses maximize social welfare as a function of a tax problem. In general, optimal tax analyses maximize social welfare as a function of individual utilities, the sum of utilities in the utilitarian case (Doligalski, 2019).

During recent years there has been a great deal of investment in optimizing the real estate income tax situation. Despite the struggles of tax officials, investors, and activists, the amount of collected tax has been reduced daily, and the average rate of growing real estate based on the current situation of real estate tax income and related unit recognition has increased. Also, real estate economic rent has resulted in a hidden and monopolized increase in taxable real estate; the increase in real estate economic rent is an unjust growth. Initially, tax is the means of income making for governments. But a more comprehensive evaluation of fiscal policies reveals that tax regulations are powerful and effective means for economic development and creating dynamic and fruitful economic movements. Fiscal policies influence economic actors, especially companies. Investment decisions, profit share, financing mode, and many other companies' operational activities may change with due attention and the country's tax principle. So, recognizing such interactions concerning the management, investors, and legislators would be useful (Izadkhasti, 2019).

There has been some research on real estate income tax; for instance, Dadkhah et al. (2014) proposed arid land modeling. There has been no study on system dynamics modeling regarding real estate income tax. The present study aims to model real estate income tax and evaluate the effectiveness of 
tax collection policies of obtained income from real estate. Concerning the complexity of the issue, system dynamics served as the most appropriate methodology for the study. System dynamics aim to provide the researchers with a useful method to reveal the mental model of decision and policymakers regarding specific issues and related weaknesses and disadvantages. Because income tax in East Azerbaijan province has grown significantly during the last years and occupied the major share of investment and employment in the province, it has created an appropriate value chain of related activities in the aforementioned areas. The present study investigates the role of real estate income tax on economic prosperity in Tabriz's and related tax feedback in civil development, leading to an increase in real estate production and current active jobs in the sphere of the province's tax capacities. Finally, based on expert opinions, some scenarios would be designed, and related feedback would be illustrated in its stimulated mode.

\section{Related Literature}

Real estate is one factor in service production and economic activities, which includes two dimensions: firstly, it deals with supplying and establishing economic and social activities for different jobs. Secondly, it relates to its profitable use. Real estate and related economic rent result in class differentiation and a gap between the poor and the rich. Therefore, the variables and effective factors on the issue must be proposed.

1) Real Estate Income Tax: According to 52nd Article of Direct Tax Law (2015), real estate income tax means an individual or legal entity's income from transferring his property rights located in Iran to be used by nonowners, after excluding established exemption which resides at the domain of real estate income tax in the law. According to the 53rd Article of Direct Tax Law, related tax revenues to rental properties include the whole rental property, whether in cash or non-cash, after reducing $25 \%$ for the expenses of depreciation and obligations of the owner concerning the leased property.

2) Economic Rent: the amount of tax collected from real estate income is influenced by the number of real estates and jobs and is affected by real estate economic rent. Economic rent has an especial meaning in the economy. In this regard, rent is the amount a production agent would achieve in its best use. To gain related rent from real estate, people invest in those sources that the expenses they spent in a specific situation equal the exact amount of the rent. Based on this, rent-seeking wastes tax resources; because tax resources are transferred from productive activities 
to non-productive activities (Del Rosal, 2011). Weak organizations like insufficiency in tax laws in the domain of real estate income tax collection and the lack of ownership rights also affect the rent-seeking process (Iqbal $\&$ Dali, 2014). In economics, economic rent is referred to any payment to an owner or factor of production over the costs needed to bring that factor into production. Economic rent results from the scarcity of the production factor (Kay \& King, 1990).

3) Speculation: speculation is another factor affecting real estate tax. Real estate speculation is taking action towards risky economic transactions to gain profits from short term and/or midterm imbalances in market value. In other words, real estate speculation means to gain profit from investment profit, interest profit, and alike instead of gaining profit from established economic ways. Such speculations result in a lack of allocation for resources in the property sector and are the main reasons for the economic crisis in sensitive monetary systems (George, 1879). The main reason for unequal income growth is private ownership in land and real estate economic rent. In a monetary economy, justice is established when economic rent and speculation is the subject of tax, and tax revenues are distributed equally among all generations. Real estate income tax reduces private ownership of properties and eliminates speculation (Alabado, 2005).

4) Advertisement: Advertising means conveying a message, news, or information to people, publishing the news in various ways to spread the news and messages. In their study, Oberholzer et al. (2008) concluded that advertisement positively affected $86 \%$ of the target population concerning tax services in South Africa. Elizabeth Branham (2009) stated that media advertisement positively affected tax payment and resulted in a significant decrease in expenses related to tax collection in America.

5) Investment: Individuals' financial capability to create employment resources through the construction of real estate and property to earn income and the profit from renting real estate and property determines the amount of investment in this research. Howton et al. (2006) investigated that tax rate decrease from $35 \%$ to $15 \%$. Immediately after decreasing the tax rate, they found out that companies proceeded to increase the dividends paid.

6) Tax Evasion: There are several definitions for tax evasion in literature. The following is a general definition: in general, tax evasion refers to illegal actions such as accounting, failure to providing official records, conducting underground economic activities, etc., to evade paying taxes. 
In this regard, and to achieve the goal, taxable income, attributed benefits, and the amount and sources of income became hidden; or the measurements resulting in tax discounts were declared more than the real amount (Alm \& Torgler, 2006; Collins \& Jones, 2009).

\subsection{Related Studies in Iran}

Symmetric results of pattern sensitivity analysis obtained by Izadkhasti and Arabmazadad (2017) showed that the equilibrium ratio of non-residential demand for goods towards residential demand increased from 1/364 to $1 / 423$ with the increased tax rate over land rent, and an increase in the efficiency in residential investment from zero to $25 \%$. Regarding the fixed rate of tax over land rent and residential investment efficiency, the investment equilibrium ratio of land for producing residential goods equaled $9 / 2$ and reached a stable situation. Finally, the investment demand equilibrium ratio of land and labor for producing non-residential goods increased from 7/422 and 3/214 to 10/144 and $3 / 758$, respectively.

Jalali (2017), in his study, indicated that housing rent increased from zero to $25 \%$, the amount of business investment, per capita production, and per capita consumption increased to 52/82, $13 / 12$, and $25 / 61$, respectively, by applying income tax in a steady situation. The efficiency rate of capital and residential investment per capita decreased to $25 \%$ and $31 / 51 \%$, respectively; this, in turn, refers to transferring investment from the residential sector towards the business sector.

Symmetric results of pattern solving and calibration by Izadkhasti (2019) showed that with increased tax rate over land rent from zero to $5 \%$, the equilibrium ratio of non-residential demand for goods towards residential demand, land demand towards labor force for the production of nonresidential goods, and investment demand towards labor force for the production of non-residential goods increased from 3/4,1/62, and $0 / 378$ to $3 / 52,1 / 73$ and $0 / 392$ respectively. The equilibrium ratio of demand for nonresidential goods towards release decreased from 6/01 to 4/83. Also, the equilibrium ratio of investment to land for housing production in urban districts was fixed at 3/05. Based on calculated values of properties in Isfahan city's urban districts, the government can earn an income equal to 37/1 thousand billion tomans via applying tax with $1 \%$ rate over land value, and 297 billion tomans via applying tax with $1 \%$ rate over construction value.

The results of the study conducted by Dadkhah (2014) indicated the total elimination of speculative demand. The related model showed that tax had a direct effect on speculation demand. As such, speculation demand tends to 
zero, and existing market demand becomes realized in its proper form. Hence, the relationship between tax and availing appropriate land encourages investors and results in land price fixation.

\subsection{Related Studies in Foreign Countries}

Tajani (2017) investigated the socio-economic factors that affected the housing market's values and examined their respective contributions in the formation of the property prices and verifying the property tax liability. The property tax is a factor that could be determined through the modest fluctuations and can lead to the revival of the property demand, generating positive effects on the construction sector, which has been currently affected by the negative real estate contingency.

The functional correlations of housing prices with the main socioeconomic variables considered (i.e., housing rents, household incomes, household consumptions, property taxes, population, and mean population age) have been explained through an econometric analysis implemented with an innovative methodology that uses a multi-objective genetic algorithm.

Eyraud (2014) concluded that the collection of tax from investment revenue achieved from speculative activities in the housing market can lead to modification of expected earnings by speculators compared to other investment opportunities. It, in turn, decreases the entry of investors with speculative temptations to the housing market.

Argger et al. (2013) investigated tax and housing price changes in 90 different residential districts in Swiss from 1985 to 2005. The results showed that income tax on higher investment led to severe fluctuations in housing market price, whereas transfer tax had no meaningful effect on the price increase. The evidence indicates that transfer tax and investment income tax are not proper tools for asset market stability.

Georgiou (2009) analyzed how tax rate influences individuals' consumptions according to some sets of data gathered from European countries. He concluded that the consumption tax rate would impose a negative (reverse) effect over the consumption rate. He claimed that the consumption tax rate based on the current economic-growth theory hinders economic growth and development. Decreased economic growth has different negative impacts on taxable incomes.

Dhaliwal et al. (2007) investigated the effect of tax rate decrease in 2003 on firms' capital cost. In this regard, they evaluated the capital cost 3 to 6 months before and 3 to 6 months after the change in tax law. They found out that the capital cost after the tax law amendment decreased averagely about 
$1.02 \%$, while the amount in those firms with higher legal shareholders was lowered because the shareholders were exempted from tax and the changes in tax rate did not affect their capital costs.

\section{Methodology}

According to the official statistics released by the Tax Affairs Administration of East Azerbaijan Tabriz Branch, there are 385,000 active real estate files in 55 taxable areas. The same number of leased jobs with an approximate annual tax capacity of 1,480,000,000,000 Rials in the real estate income tax area operates. The present study's statistical population includes taxpayers' data using income tax returns and cases under investigation by senior tax experts in the domain of real estate income tax in Tabriz city. Because the population is high, therefore, through the multi-stage cluster method, 300 individuals were selected as a research sample.

For the complexity of the issue, system dynamics was selected as the appropriate methodology for modeling. According to the proposed methodology by Sterman (2002), five steps for modeling of Tabriz city real estate income tax were considered (Figure 1).

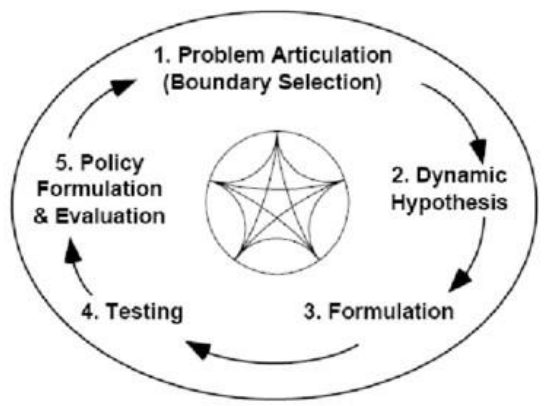

Figure 1. System Dynamics Method (Sterman, 2002)

The first step includes problem framing. In this stage, different aspects of the issue in question are investigated based on important existing literature and expert views. Data collection is of documentary research nature, and the required data is collected by referring to the Tax Affairs Administration of East Azerbaijan database. Effective key variables are identified in the same stage. Also, analyzing past trends of the problem to explore the effective key variables on problem formation is necessary for the same stage. In the second 
stage, the dynamic hypothesis of the research is made. In this stage, the problem structure is investigated. Problem structure means the variables' interaction. The dynamic hypothesis is a theory that explains system behavior. The hypothesis must explain the dynamic feature of the problem based on important feedback inside the system (Hamidizadeh, 2000). The dynamic hypothesis is compiled using subsystem, causal-loop diagrams, and a stockflow map. The third stage is devoted to formulization. In this stage, the dynamic hypothesis is turned into a simulated model by Vensim software. For this purpose, the parameters and mathematical relationships between variables are estimated. In the fourth stage, to ensure the model's validity, the simulated model was examined. The structural validity of the model is prior to its reliability (behavioral trust). Only when the model's structure is valid, the model's behavioral trust can be examined (Shi \& Gill, 2005). To achieve reliability, the following tests were used:

1) Boundary Conditions Testing: in this test, the value of some major factors of the model were tested, such as the percent of real estate income tax, the growth of population in manipulated boundary modes (exaggerated from), and changes in the degree of rationality of the model against such manipulations, were tested.

2) Behavioral Reproduction Test: In this test, the simulation results for key variables were compared with real data for the same variables. The resulting software behavior must reproduce a real data algorithm.

In the last stage, policies and scenarios are tested. In this stage, scenarios are created, and the effectiveness of each of them is evaluated in the simulated environment.

\section{Research Findings}

According to the above-mentioned methodology, the research findings are explained as follows.

\subsection{Problem Framework}

concerning the statistics from Tax Affairs Administration of East Azerbaijan, according to the below table, the tax income from real estate's lease in 2014, 2015, 2016, 2017, and 2018 is shown in 4 years. The problem relates to the existence of economic rent and speculation in the province's economy that can be identified in five years. 
Table 1

Submitted tax return declaration of real estate and jobs (numeric data)

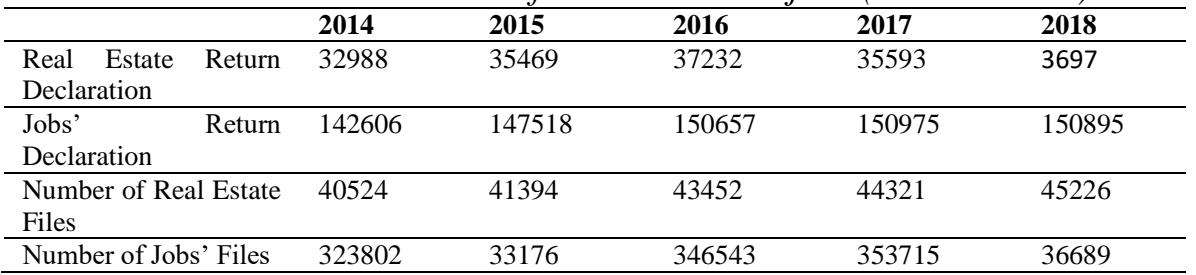

Source: Based on the information retrieved from information technology data of the Tax Affairs Organization of East Azerbaijan Province

Concerning the delivery of real estate income tax returns compared to 2015, about a 4/97\% increase was recorded in 2016. In the same year, advertisements and notifications related to tax payments were increased. According to numbers in tables 1 and 2, using public media for broadcasting comprehensive tax plan, initiating systematic tax return delivery software, sending short messages to taxpayers and issuing tax identification papers via post-bank in the same year, encouraged due attendance and tax return delivery by the half of taxpayers. Additionally, in accordance with real estate price growth, an increase in lease value of properties based on comprehensive real estate valuation book (which is evaluated annually in related commission) led to a rise in leased real estate tax return delivery.

Table 2

Collected income from real estate tax and related fines (based on million Rials)

\begin{tabular}{clllll}
\hline Year & $\begin{array}{l}\text { The Original Collected } \\
\text { Tax from Real Estate } \\
\text { Rentals }\end{array}$ & $\begin{array}{l}\text { Collected Fines } \\
\text { from Real Estate } \\
\text { Rentals }\end{array}$ & $\begin{array}{l}\text { Other } \\
\text { Collected } \\
\text { Revenues }\end{array}$ & $\begin{array}{l}\text { Sum } \\
\text { Collected } \\
\text { Income }\end{array}$ \\
\hline 2014 & $193,656,860,957$ & $9,622,368,265$ & $37,683,357$ & $203,316,912,579$ \\
2015 & $220,437,864,064$ & $8,102,478,174$ & $72,249,711$ & $228,612,591,949$ \\
2016 & $275,944,387,628$ & $13,665.916,948$ & $255,198,503$ & $289,865,503,079$ \\
2017 & $291,809,673,604$ & $10,278,829,897$ & $355,133,117$ & $302,443,636,618$ \\
2018 & $300,196,865,508$ & $11,485,124,208$ & $415,121,365$ & $410,986,426,5.8$ \\
\hline
\end{tabular}

Source: Based on the information retrieved from information technology data of the Tax Affairs Organization of East Azerbaijan Province 


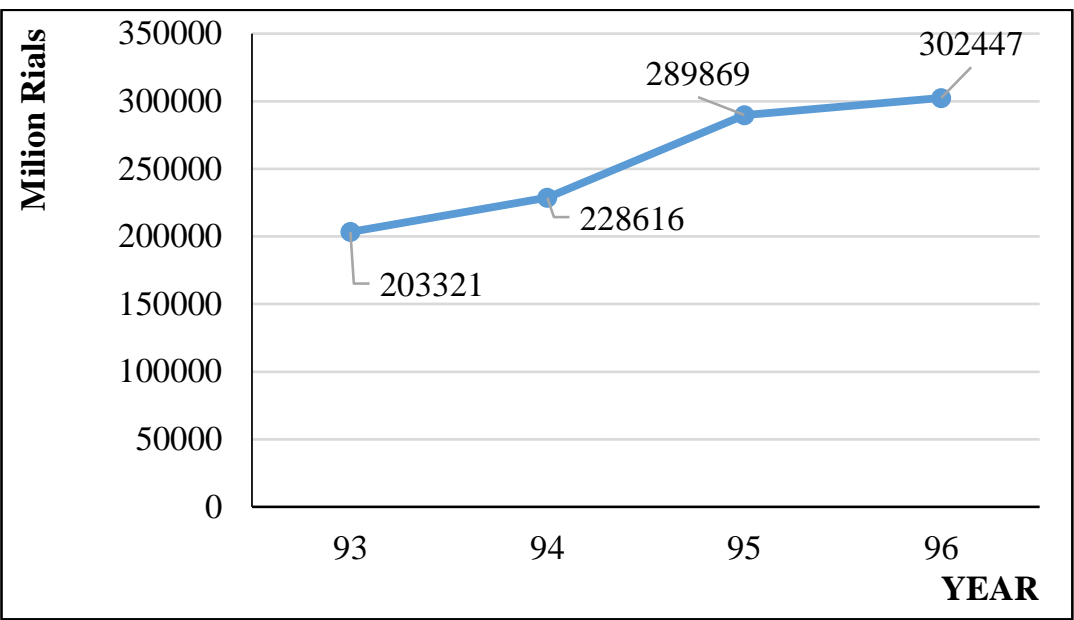

Figure 2. The Total Income Collected From Real Estate Lease.

Although the information in Table 2 and a diagram in Figure 2 show an increase in annually collected income from the real estate tax, the analysis shows that according to employment policies, the rate of supplying human resource are descending; therefore, due planning for identification of active units and real states has been weakened.

\subsection{Dynamic hypothesis}

The dynamic hypothesis explains the generation of the problem and its structure in the form of a theory. The present study illustrated the dynamic hypothesis subsystem diagram with causal-loop diagrams and stock-flow map.

\subsubsection{Subsystem Diagram and Model's Boundary Table}

A subsystem diagram is a summary of the system that shows the overall related architecture. Figure 3 illustrates the related subsystem to real estate tax. The diagram is designed based on acquired data from related documents, literature, and interviews with the domain experts. 


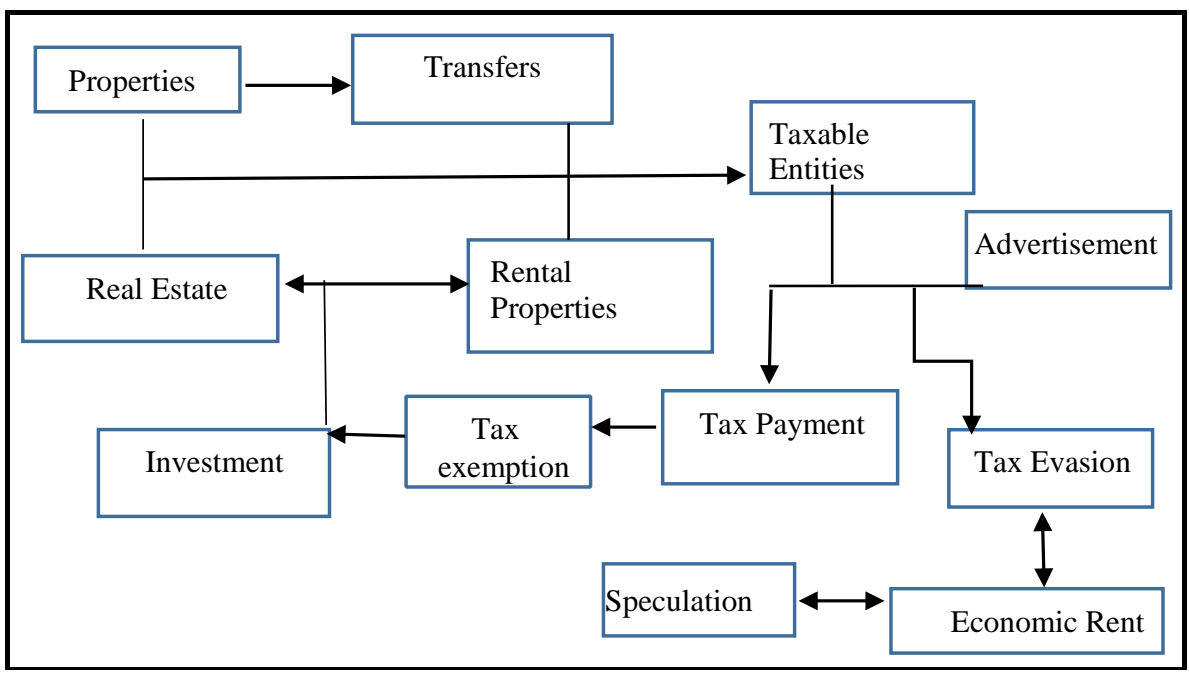

Figure 3. Subsystem Diagram.

In the above diagram, the variable of advertisement in related years has resulted in an increase in tax payment both by the owners of real states and established occupations' income through different paths like advertising before the due time of tax returns via public media, sending a required announcement to job owners, property and real estate holders. Also, regarding the negative perspective and lack of knowledge concerning how collected taxes are consumed, tax evasion increases due to natural persons' circumvention in registering lease value. According to the above diagram, due payment of rent contributes to increasing tax exemptions and collecting realestate income leases. As such, investment in the same domain increases. An increase in investment in real estate construction leads to increases in transfer tax obtained from real states. Hence, the number of included taxpayers- both natural and legal persons- increases. Therefore, according to the researchers' suppositions, the following relationships are created, leading to modeling to find different causal-loop factors.

The present study was conducted aiming at modeling the realization of real estate income tax in Tabriz city. To do so, related and effective variables to this kind of taxation were obtained through documentary and library studies and an interview with 5 managers and 3 experts in the domain of income tax. Therefore, based on research methodology, the model's boundary diagram was extracted, as shown in Table 3. 
The model's boundary diagram determines the model's territory by listing endogenous/exogenous variables and those excluded from the model.

Table 3

Model's Boundary Diagram (Vensim software output)

\begin{tabular}{lll}
\hline Endogenous Variables & Exogenous Variables & Exclude Variables \\
\hline Manufacturing Units' Tax & Inflation & Trade Variables \\
Tax Exemptions & Recession & Industry Variables \\
Financial Transparency & Safety & IT Variables \\
Speculation and Economic Rent & Media & Global Circumstances \\
Providing Government's Expenses & & Culture \\
Social Support & & \\
Economic Support & & \\
Employment & & \\
Investment & & \\
Demand for Real Estates & \\
Delay in Tax Payment & \\
Business Environment & & \\
Construction & & \\
Population & & \\
\hline
\end{tabular}

\subsubsection{Causal-Loop Diagram}

The subsystem diagram illustrates a holistic view of the model's scope and structure. For a comprehensive explanation of the causality relationships among variables, causal-loop diagrams (CLDs) are appropriate. These diagrams are flexible and useful tools for illustrating feedback structures of systems with any given domain. The Causal-loop diagram which is depicted in Figure 4 shows the structure of real estate tax according to seven variables of tax, real estate, economic rent, speculation, amount of investment, tax evasion, and advertisement. 


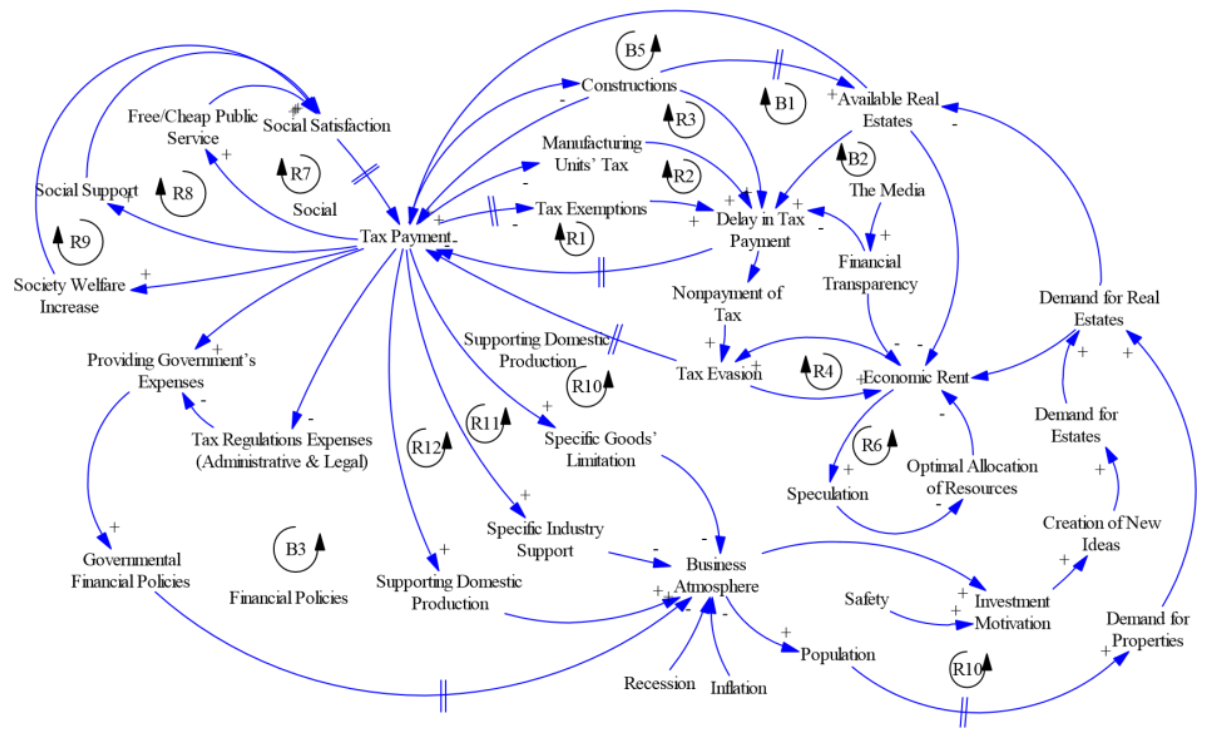

Figure 4. Research Model Causal-Loop Diagram.

Some important loops about Figure 4 are explained below:

- R7 increase loop: this loop is one entry for expending tax and providing cheap or free public services. An increase in these services increases social satisfaction and encourages people to pay due to taxes. An increase in collected tax increases public services.

- R8 increase loop: with an increase in paid tax, social support increases. In turn, increasing socio-economic capability brings about increased social satisfaction. Therefore, people are more encouraged to pay due taxes. In this way, some of the tax is allocated to provide social support. For example, allocating collected tax to charity organizations like Relief Foundation, State Welfare, Municipality, etc., results in improved social welfare.

- R10 increase loop: increased paid tax helps the government to provide unpredicted expenses. Hence, the government runs financial policies better and proceeds to improve the business environment. But what affects the business environment directly as external factors relate to inflation and recession in the economy. Therefore, increased paid tax can influence (positive/negative) public financial policies and improve the business environment. 
- R5 increase loop: with an improving business environment, the demand for real estate and properties increases, decreasing the number of real estates and properties. It increases the collected tax. Also, with increased paid tax, administrative and regulative expenses decrease, which imposes a positive effect on public expenses.

\subsubsection{Stock-Flow Map}

Causality diagrams emphasize feedback structures, while stock-flow maps emphasize physical flow. Therefore, in order to show the flow and accumulation of materials, money, and information in the system, the stockflow maps are useful. Figure 5 shows the stock-flow map of tax on real estate.

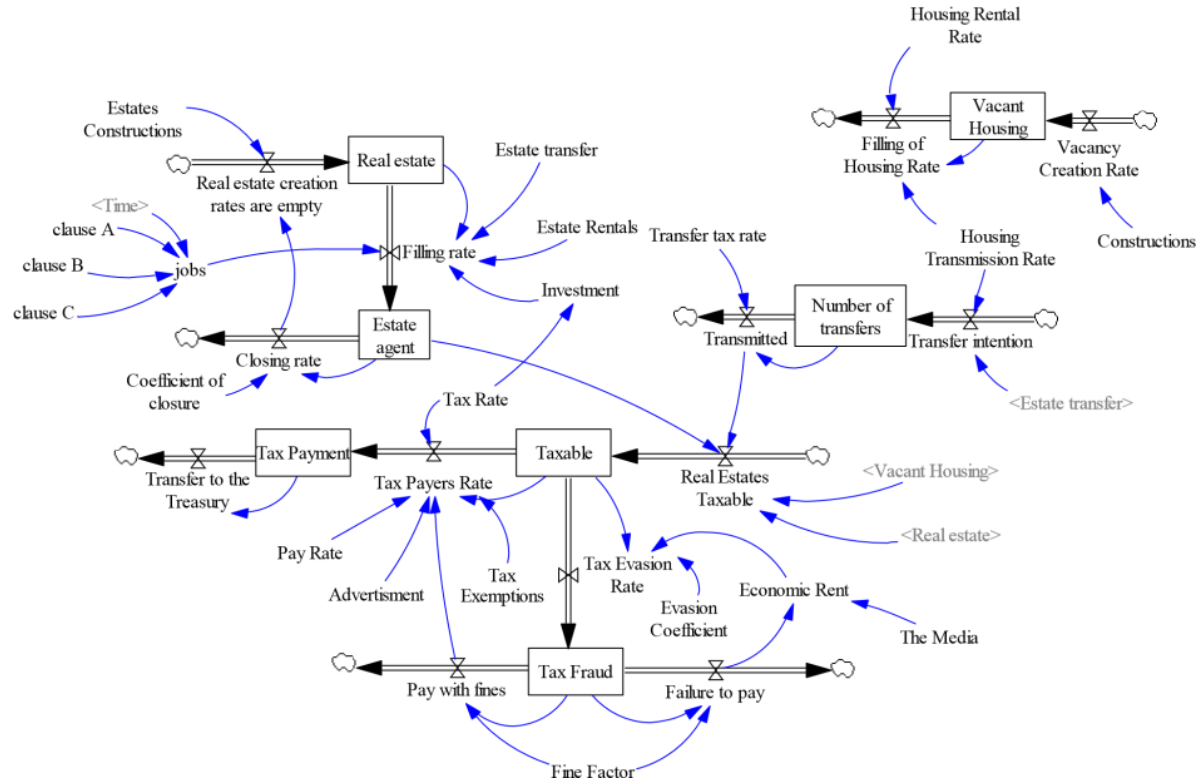

Figure 5. Stock-Flow Diagram of Tax on Real Estates.

\subsection{Formulization}

Based on existing literature and experts' points of view, the relationship among the variables was identified in the shape of some formulas to simulate the model. Table 4 shows the formulization of relationships among research variables in Figure 5, deducted from Vensim software's output. 
Table 4

Model's formula table

\begin{tabular}{|c|c|c|c|}
\hline Name of Variable & Formula & Name of Variable & Formula \\
\hline $\begin{array}{l}\text { Vacant Housing } \\
\text { Creation Rate }\end{array}$ & $\begin{array}{l}\text { Annual Construction } \\
\text { Rate }\end{array}$ & $\begin{array}{l}\text { Vacant Real Estate } \\
\text { Creation Rate }\end{array}$ & $\begin{array}{lr}\text { Real } & \text { Estate } \\
\text { Construction } & + \\
\text { Stoppage Rate } & \end{array}$ \\
\hline $\begin{array}{l}\text { Rate of Occupied } \\
\text { Housing }\end{array}$ & $\begin{array}{l}\text { Vacant Housing * } \\
\text { (Rate of } \\
\text { Rented Housing + Rate } \\
\text { of } \quad \text { Transferred } \\
\text { Housing) }\end{array}$ & $\begin{array}{l}\text { Rate of Occupying } \\
\text { [Real Estate] (Delay) }\end{array}$ & $\begin{array}{l}\text { Investment * Vacant } \\
\text { Real } \\
\text { Estate + Real Estate } \\
\text { Transfer * Vacant Real } \\
\text { Estate + Occupations + } \\
\text { Real Estate Rent * } \\
\text { Vacant Real Estate }\end{array}$ \\
\hline Vacant Housing & $\begin{array}{lr}\text { Integral } & \text { (Vacant } \\
\text { Housing } & \\
\text { Creation } & \text { Rate }+ \\
\text { Occupied } & \text { Housing } \\
\text { Rate) } & \\
\end{array}$ & Vacant Real Estate & $\begin{array}{l}\text { Integral (Vacant Real } \\
\text { Estate Creation Rate - } \\
\text { Occupying Rate) }\end{array}$ \\
\hline Transfer Intention & $\begin{array}{l}\text { Transferred Housing } \\
\text { Rate + Real Estate } \\
\text { Transfer }\end{array}$ & $\begin{array}{l}\text { Rate of Stoppage [Real } \\
\text { Estate] (Delay) }\end{array}$ & $\begin{array}{l}\text { Real Estate with Agent } \\
* \text { Stoppage Coefficient }\end{array}$ \\
\hline Transferred & $\begin{array}{l}\text { The Number of } \\
\text { Transfers * }\end{array}$ & Real Estate with Agent & $\begin{array}{ll}\text { Integral } & \text { (Occupying } \\
\text { Rate - } & \\
\end{array}$ \\
\hline & Transfer Tax Rate & & Stoppage Rate) \\
\hline $\begin{array}{l}\text { The Number of } \\
\text { Transfers }\end{array}$ & $\begin{array}{lr}\text { Integral } & \text { (Transfer } \\
\text { Intention } & - \\
\text { Transferred) } & \\
\end{array}$ & Occupations & $\begin{array}{l}\text { Paragraph a + (Time) } \\
\text { Paragraph b }+ \text { (Time) } \\
\text { Paragraph c (Time) }\end{array}$ \\
\hline Investment & $\begin{array}{l}\text { Random Uniform } \\
(0.05, \\
0.02,0) \text { Tax Rate }\end{array}$ & Taxable Real Estates & $\begin{array}{lll}\text { Vacant } & \text { Housing } & + \\
\text { Vacant } & & \\
\text { Real } & \text { Estate } & + \\
\text { Transferred }+ & \text { Real } \\
\text { Estate with Agent }\end{array}$ \\
\hline Taxable & $\begin{array}{l}\text { Integral (Taxable Real } \\
\text { Estates - Tax Evasion } \\
\text { Rate } \\
\text { - Taxpayers' Rate) } \\
\end{array}$ & Tax Evasion Rate & $\begin{array}{l}\text { Taxable * Evasion } \\
\text { Coefficient / Economic } \\
\text { Rent }\end{array}$ \\
\hline The Rate of Taxpayers & $\begin{array}{l}\text { Taxable * Payment } \\
\text { Rate + (Payment with } \\
\text { Fine) + Advertisement } \\
* \text { Tax } \\
\text { Exemption) * Taxable } \\
\text { / Tax Rate }\end{array}$ & Tax Evasion & $\begin{array}{l}\text { Integral (Tax Evasion } \\
\text { Rate } \\
\text { - Evasion - Payment } \\
\text { with Fine) }\end{array}$ \\
\hline Evasion & $\begin{array}{l}\text { Tax Evasion } *(1- \\
\text { Fine Coefficient })\end{array}$ & Economic Rent & Evasion / The Media \\
\hline $\begin{array}{lll}\begin{array}{l}\text { Payment } \\
\text { (Delayed) }\end{array} & \text { with } & \text { Fine } \\
\end{array}$ & $\begin{array}{l}\text { Tax Evasion * (Fine } \\
\text { Coefficient) }\end{array}$ & $\begin{array}{lll}\begin{array}{l}\text { Transfer } \\
\text { Treasury }\end{array} & \text { to the } \\
\end{array}$ & Tax Payment \\
\hline The Rate of Taxpayers & $\begin{array}{l}\text { Taxable * Payment } \\
\text { Rate + } \\
(\text { Payment with Fine) + } \\
\text { (Advertisement * Tax } \\
\text { Exemption)* Taxable) } \\
\text { / Tax Rate }\end{array}$ & Tax Payment & $\begin{array}{l}\text { Integral (TaxPayers' } \\
\text { Rate - Transfer to the } \\
\text { Treasury) }\end{array}$ \\
\hline
\end{tabular}




\subsection{Testing the Model}

To ensure the validity of the research model, behavioral reproduction, error calculation, boundary conditions, and sensitivity tests were applied.

\subsubsection{Behavioral Reproduction Test}

The test aims to compare the results of the simulated model with real data. For this purpose, at first, some variables were selected among the research's key variables, including tax payments and taxpayers. Then the status of the variables for the period between 2014 and 2017 was simulated, and the results were compared with real data. Figures 6 and 7 show the comparisons so that the simulated model repeats the pattern of variables' real behavior approximately.

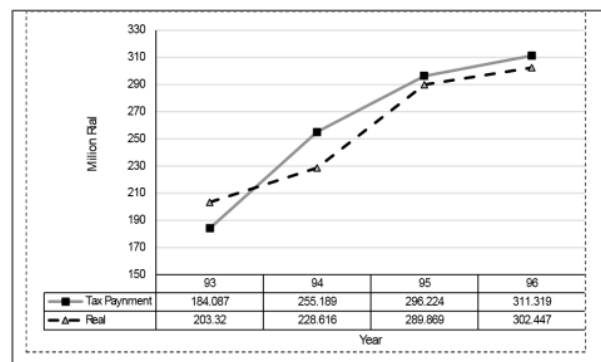

Figure 6. Repeat behavior test for paid tax variable

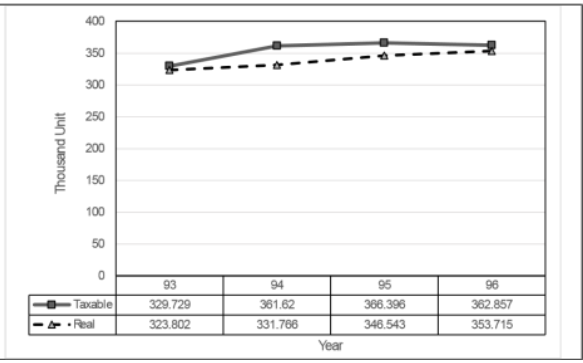

Figure 7. Repeat test for taxable variable

Source: Researcher's calculations based on data from the East Azerbaijan Province Tax Affairs Organization

\subsubsection{Error Calculation Test}

In addition to the behavioral reproduction pattern, the key variables' error was calculated as follows to ensure simulation results. In testing so, the comparison of two models using linear regression among real and calculated values was made using RMSPE and UT.

Root Mean Square Percentage Error (RMSPE ${ }^{2}$ ): in math and statistics, the mean square error is a method of estimating the error rate, which is the difference between the actual values and the estimated. MSE is almost positive (not zero) for two reasons; first, it is not random, and second, it does not calculate the information estimator that can produce more accurate estimates. So, the index always owns a non-negative value, and the more it approaches zero, the less the error is.

According to this index, the less the difference between real data and simulated ones, the more reliable the simulation results are. In other words, 
the more the value of RMSPE approaches zero, the less the error would be, and approaching 100 means more errors. In order to calculate RMSPE, the following formulas were used. In this equation, the standard deviation of simulated data $\left(\mathrm{y}^{5}\right)$ is calculated based on the primary data $\left(\mathrm{y}^{\mathrm{a}}\right)$, and $\theta$ indicated the number of observations.

RMSPE $=\sqrt{\frac{1}{\theta} \sum_{\mathrm{i}=1}^{\theta}\left(\frac{\mathrm{y}_{\mathrm{T}+\mathrm{i}}^{\mathrm{s}}-\mathrm{y}_{\mathrm{T}+\mathrm{i}}^{\mathrm{a}}}{\mathrm{y}_{\mathrm{T}+\mathrm{i}}^{\mathrm{a}}}\right)^{2}} \times 100$

Identifying Roots of Errors: another method for evaluating the deviation of simulated values from real data is U-Theil's (UT) calculation, which is as follow:

$U T=\sqrt{\frac{\frac{1}{\theta} \sum_{i=1}^{\theta}\left(y_{T+i}^{s}-y_{T+i}^{a}\right)^{2}}{\frac{1}{\theta} \sum_{i=1}^{\theta}\left(y_{T+i}^{s}\right)^{2}+\frac{1}{\theta} \sum_{i=1}^{\theta}\left(y_{T+i}^{a}\right)^{2}}} \times 100$

The value of UT is always between zero and one. The more the value approaches zero, the more the simulated values and real data show less deviation from one another.

The following table shows the statistical test results regarding the variables of paid tax and taxable units. The information in the table indicates the fitness of simulated data concerning the real ones. Therefore, the model results can be used for scenario making and presenting amendment suggestions in the next steps.

Table 5

The results of statistical tests related to model validation

\begin{tabular}{|l|l|l|}
\hline Name of Test & Paid Tax & Taxable \\
\hline RMSPE (\%) & $7 / 71 \%$ & $5 / 56 \%$ \\
\hline UT & $0 / 0712$ & $0 / 0128$ \\
\hline
\end{tabular}

\subsubsection{Boundary Conditions}

To investigate the model's reaction in boundary conditions, some tests were done as follows. With an increase in the transfer tax rate to its maximum amount, as shown in Figure 8, the transfer interactions tend to zero. It is expectable. By the maximum value, we mean number 1 , which is considered as $100 \%$ tax. 


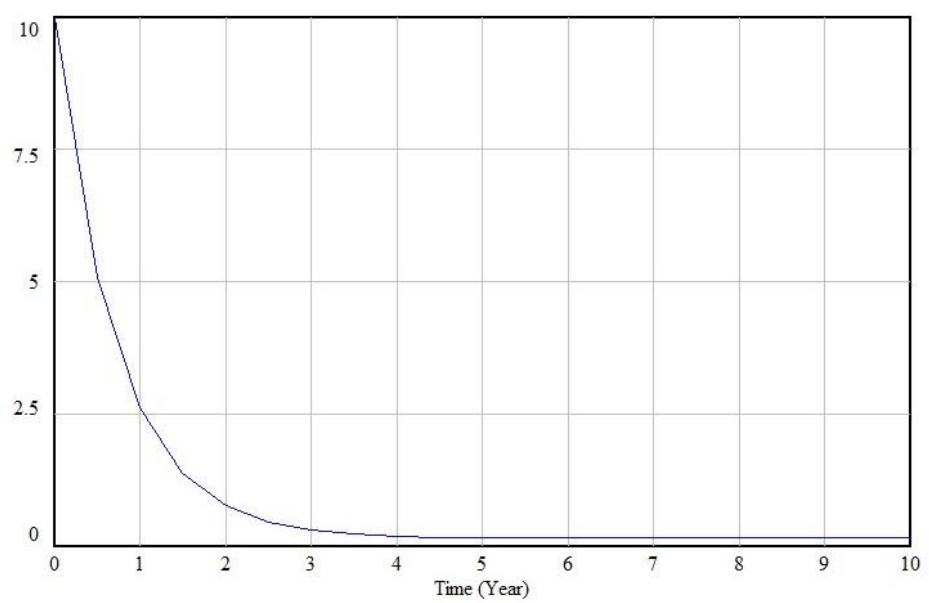

Figure 8. Boundary condition Test for the variable of the Number of Transfers.

\subsubsection{Sensitivity Analysis}

To analyze the model sensitivity against the tax rate's key variable, with the reduction of the tax rate value to zero, it is observed that the number of taxpayers increases linearly and continuously. On the other hand, the reduction in transfer rates and housing leads to zero, and the number of vacant houses increases concerning constructional operations in the same sector.

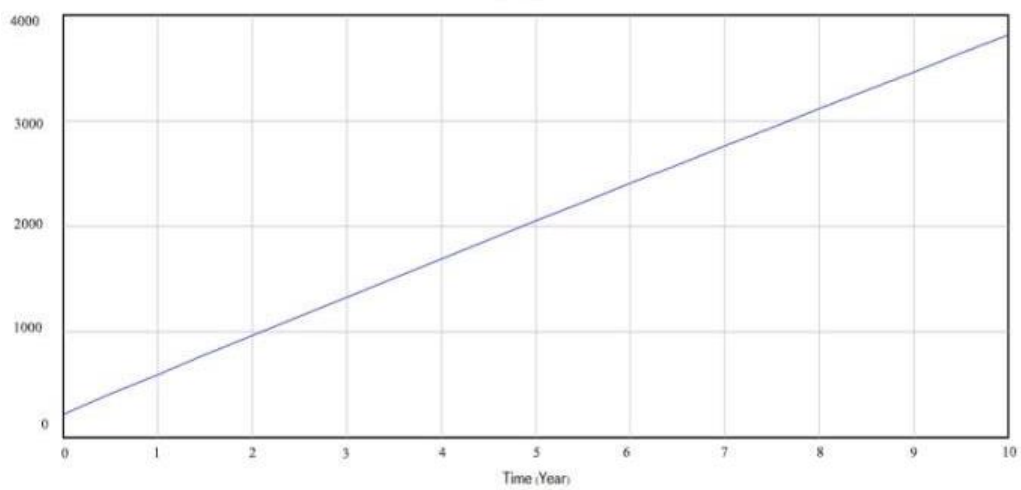

Figure 9. Sensitivity Analysis for the Taxable Variable. 


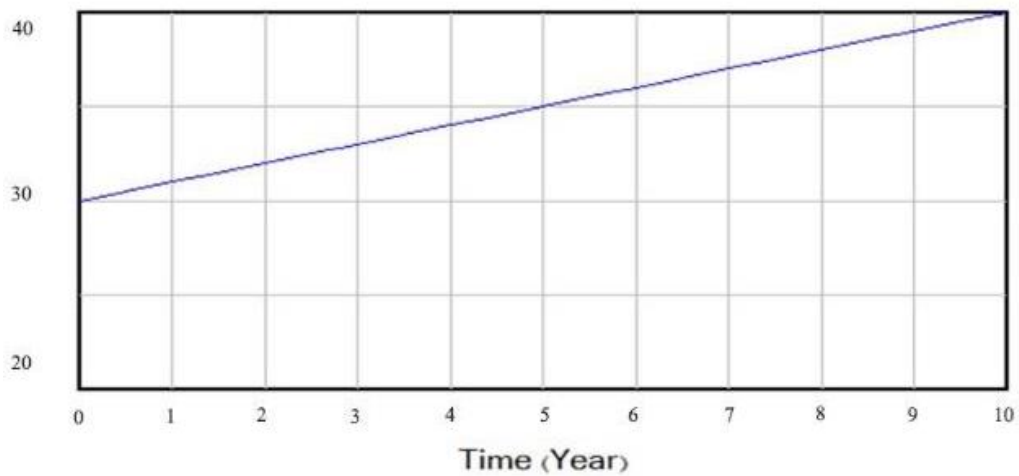

Figure 10. Sensitivity Analysis for the Vacancy Variable.

\subsection{Assessing Policies and Scenarios}

In this phase, the policies and scenarios that can realize real estate tax recognition are analyzed.

Increasing Advertisement (information) and its Effect on Tax Payment: As shown in the figure below, increasing advertisement about paying tax leads to an increase in the paid tax.

Decreasing the Related Economic Rent to Real Estates through the Media: one of the influential factors in tax evasion is economic rent and evasion pathways created by it. The media, as leverage in clarifying individuals' income and business enterprises, can significantly collect tax revenues. As it can be seen in Figure 11, with increasing the media strengths in clarification, the amount of real estate economic rent reduces. Consequently, it contributes to the reduction in the number of tax evasions.

Decreasing Tax Rate: modeling a decreased tax rate shows that the collected tax revenue increases with decreasing tax rate. Also, by decreasing the transfer tax rate for real estate, the amount of transfer increases significantly, increasing collected income from real estate transfer and paid tax by taxpayers.

Transparency Scenario via the Media and its Impact over Taxable Entities: introducing big taxpayers and clarifying the amount of income produced by natural and legal entities residing at rental real estates via the media and also, determining the rate of annual production and/or service delivery by correct introduction, results in increasing self-declaration by taxpayers and receiving their annual settlement of accounts. As such, it 
contributes to motivating individuals to pay tax and increasing collected tax income consequently.

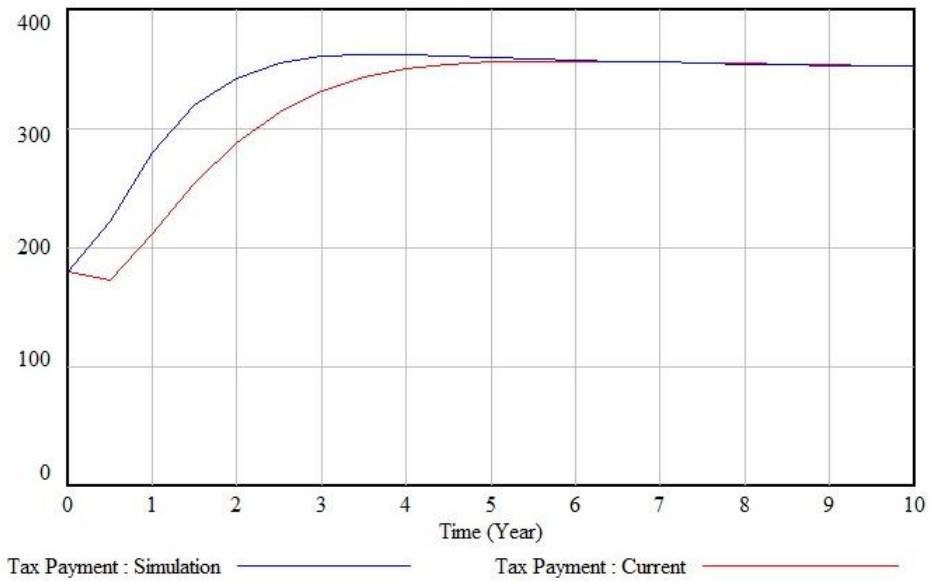

Figure 11. Increasing the Advertising and Its Impact on Paying Taxes Scenario.

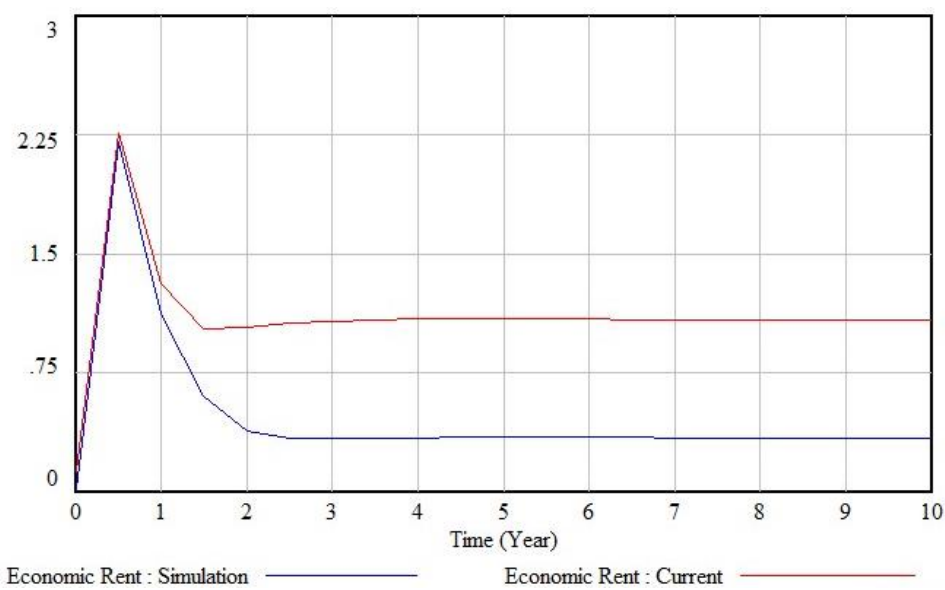

Figure 12. Transparency through Media and Impact on Rent Scenario. 


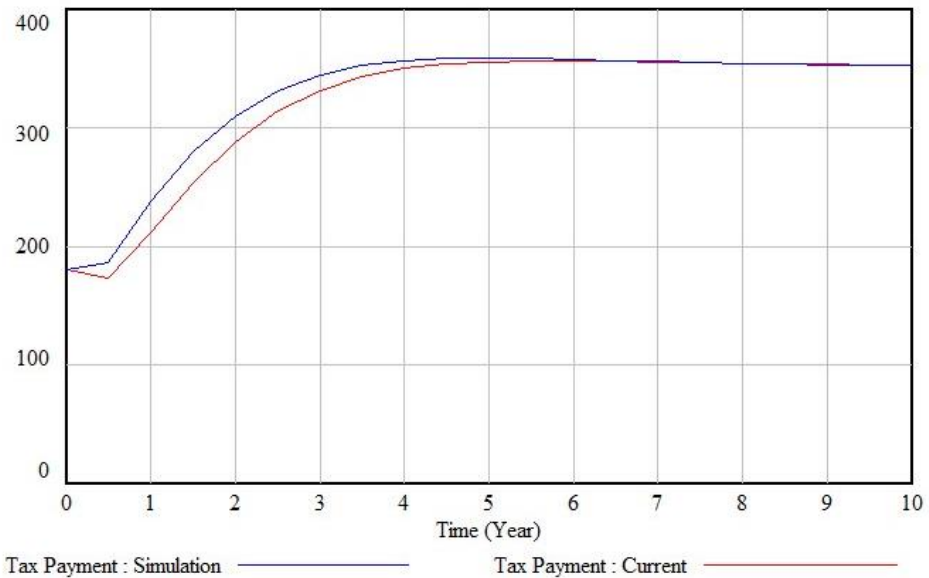

Figure 13. The Scenario of Reducing Tax Rates and Their Impact on Tax Payments.

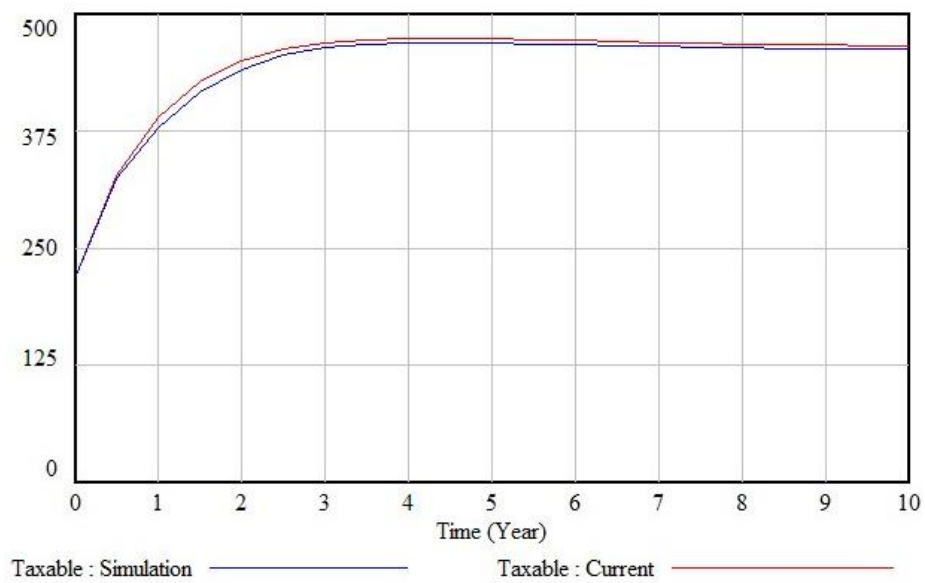

Figure 14. Transparency through Media and Impact on Taxpayers Scenario.

\section{Discussion and Conclusion}

The issue of real estate income tax is a complex matter, and lots of variables in interaction with one another form the structure of real estate tax. Sometimes, without understanding such complexity, the policymakers fall short of perceiving the subject correctly and may introduce some solutions that not only do not solve the problems but also worsen them. Therefore, system dynamics was selected as the appropriate methodology for modeling 
complex issues mentioned in this study to identify real estate tax modeling. Real estate modeling enriches the policymakers' vision beforehand. In other words, the dynamic structure of the problem through the use of subsystem, causal-loop diagrams, and stock-flow map manifests taxing complexities and possible misunderstandings. Besides, four scenarios with possible tax payment effects related to real estate tax and some other influential factors like economic rent were analyzed. Three variables of paying tax by taxpayers, the amount of economic rent, and the number of taxable entities are among the most important factors that need to be improved by tax policies. According to the related literature and the experts' viewpoints in the field, the advertisement scenarios increase, real estate economic rate, decreasing tax rate, and taxpayers' financial transparency were investigated.

Advertisement increase was the first analyzed scenario. The simulation results showed that the increased advertisement about due submission of tax returns led to the growth of increased collected real estate tax. Informing and advertising contribute to taxpayers' awareness about accounts' settlement, ontime payment exemptions, and exemption declared in Article 57 of Direct Tax Law. Also, informing people about the current value of the real estate in Tabriz city according to the valuing booklet compiled by the Province Tax Affairs Administration and related fineries encourages taxpayers to pay due tax to the government. The results of the study conducted by Abdollahi (2005) approved the above-mentioned concerns. One of the critical variables to be controlled is real estate economic rent. The second scenario evaluated the role of the media in decreasing real estate economic rent. It revealed that empowering the media's role in clarification leads to the reduction of tax evasion and real estate economic rent. Transparency contributed to the use of on-time registration mechanisms in legal books and documentations, awareness of taxpayers about representable documents to tax affairs administration, awareness of taxpayers about the consequent fines resulting from not delivering sufficient documents on- time, awareness of taxable businesses active in rental properties from the way registration for or installation of point of sale must be done, decreased involuntary tax evasion and finally decreased real estate economic rent.

The third scenario, despite public perception, emphasized the tax rate decrease. This scenario showed that the tax rate decreased by increasing real estate transfer significantly. In turn, it resulted in increased income from real estate transfer and the amount of paid tax. Also, the tax rate decrease contributed to increased self-declaration by taxpayers active in the real estate domain, which finally would lead to increased collected tax. The study's 
findings conducted by Alijanzadeh (2002) approved the decreased tax rate's role in increasing tax incomes.

Finally, the fourth scenario is the media's transparency scenario, increased self-declaration by taxpayers, received their annual settlement of accounts, and increased collected tax. Also, establishing tax transparency through competent authorities like registration of real estate lease contacts at notary publics and conditioning the real amount of property lease value in official lease contracts resulted in decreased tax evasion and due collection of the real estate tax. It seems that instead of the increasing tax rate, taxpayers must be identified to increase the number of taxable entities. It can be achieved through the media and establishing a certain mechanism for rewarding those who identify and introduce taxpayers. Among the four scenarios, the third one, i.e., decreasing tax rate, seems to impose the most influential impact on decreasing tax evasion and real estate tax collection.

According to the present study results, planning to decrease the tax rate over real estate income contributes to reduced involuntary tax evasion, ontime tax self-declaration, and an increased tendency to pay related tax. Therefore, it is suggested that to prevent tax evasion and decrease related property economic rent, related authorities should bring about an increased tendency to pay tax in due time through decreased tax rates and increased control of tax assessors.

The present study, just like any other study, had its limitations. Among the limitations of the current study, regardless of some variables - although they were influential in real estate tax-related affairs, they could not be included in the model for different reasons. For example, cultural variables like the tendency of some business owners to pay religious funds instead of a tax, money laundering, etc., were not included in the model. Future studies can eliminate such limitations by broadening the scope of the model. Also, according to the collected statistics and information from public organizations in Tabriz city, the model's past looking horizons could only encompass the period of 2014 to 2017. Hence, tracing the effective factors in increasing real estate income tax could not cover sufficient past looking horizons.

\section{References}

Alabado, R. P. (2005). Managing vacant lands within central business districts: Implications of implementing idle land taxation. Banwa: The Academic Journal of UP Mindanao, 2(1), 63-83.

Alijanzadeh, M. (2002). Optimal Tax Rate in Iran's Economy; MA Thesis, Faculty of Economics, University of Tehran. 
Alm, J., \& Torgler, B. (2006). Culture differences and tax morale in the United States and in Europe. Journal of Economic Psychology, 27(2), 224-246.

Aregger, N., Brown, M., \& Rossi, E. (2013). Transaction Taxes, Capital Gains, and House Prices. Swiss National Bank Working Papers, 2013-02.

Bogataj, D., Mc Donnell., D.R., \& Bogataj, M. (2016). Management, Financing, and Taxation of Housing Stock in the Shrinking Cities of Aging Societies, Journal of Production Economics, 181, 2-13

Branham, E. (2009). Closing the Tax Gap: Encouraging Voluntary Compliance through Mass-Media Publication of High-Profile Tax Issues, Hastings Law Journal, 60(6), 1507-1533.

Del Rosal, I. (2011). The empirical measurement of rent-seeking costs. Journal of Economic Surveys, 25(2), 298-325.

Diamond, P., \& Saez, E. (2011). The Case for A Progressive Tax: From Basic Research to Policy Recommendations. Journal of Economic Perspectives, 25(4), 165-90.

Direct Tax Law. 2015. (Iran) Ratified on 16/02/2002.

Dhaliwal, D., Krull, L., \& Li, O. Z. (2007). Did the 2003 Tax Act Reduce the Cost of Equity Capital?. Journal of Accounting and Economics, 43(1), 121-150.

Doligalski, P. (2019). Optimal Income Taxation and Commitment on the Labor Market. Society for Economic Dynamics 2019 Meeting Papers, 422.

Eyraud, L. (2014). Reforming Capital Taxation in Italy. (IMF Working Papers 14/6). Washington, D.C.: International Monetary Fund.

George, H. (1879). Progress and Poverty: An Inquiry into the Cause of Industrial Depressions, and of Increase of Want with Increase of Wealth: The Remendy. New York: D. Appleton.

Georgiou, M. N. (2009). The Impact of Consumption Tax Rate on Consumption-A Panel Data Analysis for European Countries (1995-2007). Available at SSRN 1529242.

Hamidizadeh, G. (2000). Research Methodology with Thesis Writing Approach; No. 1, Tehran, Baztab Publications, pp. 21-23.

Howton, S., \& Howton, S. D. (2006). The Corporate Response to the 2003 Dividend Tax Cut. Journal of Applied Finance, 16(1).

Iqbal, N., \& Daly, V. (2014). Rent seeking opportunities and economic growth in transitional economies. Economic Modelling, 37, 16-22.

Izadkhasti, H (2019) Analyzing the Performance, Collection Efficiency and Implementation Challenges of Value Added Tax in Iran, Journal of Tax Research, 25(36), 43-80.

Izadkhasti, H., \& Arabmazar, A. (2017) Tax on Land Rent and Capital Housing: General Equilibrium Approach, Quarterly Journal of Quantitative Economics, 14(3). 1-25.

Jalali, A. (2017). Reforming the Tax System by Assessing the Feasibility of Applying Tax on Rental Income in Iran: Neoclassic Growth Approach, M.A. Thesis, Shahid Beheshti University. 
McCluskey, W., Lay-Cheng, L., \& Davis, P. (2007). Land value taxation: an international overview. American Journal of Economics and Sociology, 56(2007), 207-214.

Oberholzer, R., de Kock, D., \& Walker, K. M. (2008). Routes of persuasion utilised in the advertising appeals of the South African Revenue Service among taxpayers in Gauteng, South Africa. Southern African Business Review, 12(2).

Shi, T., \& Gill, R. (2005). Developing effective policies for the sustainable development of ecological agriculture in China: the case study of Jinshan County with a systems dynamics model. Ecological Economics, 53(2), 223-246.

Sikka, P. (2017). Accounting and Taxation: Conjoined Twins or Separate Siblings? Accounting Forum, 41(4), 390-405.

Sterman, J. D. (2002). System Dynamics: Systems Thinking and Modeling for a Complex World. Massachusetts Institute of Technology Engineering Systems Division Working Paper Series ESD-WP-2003-01.13

Tajani, F., Morano, P., Torre, C. M., \& Di Liddo, F. (2017). An analysis of the influence of property tax on housing prices in the Apulia region (Italy). Buildings, $7(3), 67$. 